\title{
The Effect of Tax Stimulus during the Covid-19 Pandemic in Improving the Performance of Taxpayers
}

\author{
Hadion Wijoyo* \\ STMIK Dharmapala Riau \\ Riau, Indonesia \\ Hadion.wijoyo@lecturer.stmikdharmap \\ alariau.ac.id \\ Dodi Prasada \\ Universitas Pamulang \\ Pamulang, Indonesia \\ dosen02454@unpam.ac.id \\ Agus Sudarsono \\ Universitas Pamulang \\ Pamulang, Indonesia \\ dosen02473@unpam.ac.id
}

\author{
Mada Faisal Akbar \\ Universitas Pamulang \\ Pamulang, Indonesia \\ dosen02471@unpam.ac.id
}

\author{
Abdul Rahman Safiih \\ Universitas Pamulang \\ Pamulang, Indonesia \\ dosen02457@unpam.ac.id
}

\author{
Ade Yusuf \\ Universitas Pamulang \\ Pamulang, Indonesia \\ dosen02604@unpam.ac.id
}

\author{
W Widiyanti \\ STMIK Dharmapala Riau \\ Riau, Indonesia \\ Widiyanti@lecturer.stmikdharmapalariau.ac.id
}

\begin{abstract}
Due to the Covid-19 pandemic outbreak, the economy tends to experience sluggishness, to increase the enthusiasm of the business world, especially MSMEs, the government issued a policy of providing various fiscal stimuli. In this study, the authors focused on the direct effect of the provision of stimulus on the field of MSMEs. A qualitative method with purposive sampling data collection technique was used in the study. The MSME which the writer took as the sample of the study is the MSME which is engaged in the culinary field. From the results of research, MSME business actors do not know the type of fiscal stimulus and assume that government assistance such as Pre-employment, PKH and others is a fiscal stimulus and structured counseling of which MSME business actors who are taxpayers can take advantage.
\end{abstract}

Keywords—tax stimulus, taxpayers, covid-19.

\section{INTRODUCTION}

Apart from the budget function, taxes also have a regulatory function [1], serving to provide economic balance in society. During the Covid-19 Pandemic, the government through the Directorate General of Taxes provided a lot of stimuli, such as exemption from hotel and restaurant taxes in tourist areas consisting of 33 regencies and cities, and also provides discounted flight tickets of $30 \%$ from $25 \%$ of flight seats to several tourist areas that have been affected by the decline in the number of tourists. In the MSME sector, the Government also provides tax stimulus in the form of Final Income Tax borne by the government, and other reliefs aiming to stimulate the MSME sector which has the largest number and has a direct impact on the consequences of the Covid-19 Pandemic [2]. Taxes are mandatory contributions to the State based on the law without receiving direct contributions [3]. Literatim, tax collection is enforced because it is based on law. In practice, however, the government implements the function of regulating (regular) so that there is economic balance in society, especially economic disparities in society.

This research is to observe to what extent the effect of providing MSME stimuli is to improve the family economy, at least to survive a pandemic. The MSME sector is the focus of the author's research because there are 67 million MSMEs registered in Indonesia [4]. With various types of businesses managed by MSMEs, it is most likely that they have a positive effect on the National economy which is experiencing a sluggishness [5].

From the results of the author's interviews with informants (MSME actors), that information obtained by business actors expects the government to provide tax exemptions such as income tax $(\mathrm{PPh})$ Article 21, Article 25, and also provides convenience in the process of obtaining raw materials, especially those from outside of customs. Through the Directorate General of Taxes, the Government has issued a stimulus in the form of a final income tax facility with a rate of 0.5 percent which is borne by the government. Thus, taxpayers do not need to make tax payments. However, from the informants, the authors found that MSME business actors did not know about the stimulus at all and expected the Government to disseminate information on the use of the stimulus, starting from registration procedures and others.

\section{METHODS}

The research was conducted using a qualitative approach. Maleong [6] defines qualitative research that is used to understand the phenomena experienced by research subjects, for example, behavior, perceptions, motivation, actions, and others. Research is carried out holistically by means of descriptions in the form of words and language, in a special nature, and utilizes various scientific methods. Qualitative 
research aims to obtain a complete picture of something according to the views of the information studied [7].

Data in this study were collected by using non-test techniques, by means of observation, interviews, and documentation. The process of observation and interviews is prioritized in data collection because it is expected to be able to reveal information about healthy lifestyles. Data collection was carried out in deep and natural way. Data collection instruments were in the form of observation guidelines, interview guidelines, and documentation. This study used a descriptive analysis technique, which is a type of research that aims to provide a description or analysis of a situation as clearly as possible without any special treatment of the object under study. In descriptive research using a cross-sectional survey, which is a data collection method, where the information collected takes several weeks due to the transportation situation and time constraints [8].

Observation is an activity of discerning and observing to obtain data that can be used to provide a conclusion or diagnosis. The purpose of observation is to describe the observed environment, activities that have taken place individually.

Interviews are conversations conducted by two parties, namely interviewers who ask questions and interviewees who provide answers to these questions [9]. Interviews were used to explore and obtain information to answer the research questions that have been determined in this study, and interview techniques are the main means of data collection in this study.

This research began by collecting all information related to the subject matter, followed by analyzing the information based on theory, expert statements, and conditions in the field. The information being analyzed relates to the negative impacts caused by the COVID-19 pandemic and what tax incentives have been issued by the government to address these impacts. Comparing this information with theory, expert statements, and conditions in the field this study will draw conclusions on the needs of the MSME sector in dealing with the negative impacts of the COVID19 pandemic, the benefits of these incentives in the MSME sector, and alternative tax incentive policy solutions in overcoming economic problems in the MSME sector due to the COVID-19 pandemic [10].

The participants of the study involve 20 MSME business actors who were the sample of the study taken purposively. The instruments in this study were statements in the form of questionnaires given online which were distributed to the research participants.

\section{RESULTS AND DISCUSSION}

The research stage was to distribute questions using a questionnaire to $20 \mathrm{MSME}$ entrepreneurs. The answers to the distributed questionnaires can be seen in the tables below.

TABLE I. THE EFFECT OF TAX STIMULUS DURING A PANDEMIC ON BUILDING EXCITEMENT OF BUSINESS

\begin{tabular}{|c|c|c|}
\hline Alternative answers & Frequency & Percentage \\
\hline Yes & 10 & 50 \\
\hline No & 10 & 50 \\
\hline Answer & $\mathbf{2 0}$ & $\mathbf{1 0 0}$ \\
\hline
\end{tabular}

As can be seen in Table I as many as $50 \%$ of MSME business actors felt that the tax stimulus provided by the Government build their business excited. This indicates that taxes were too burdensome during the Pandemic with people's purchasing power tending to decline.

TABLE II. UNDERSTANDING OF THE TYPES OF THE PROVIDED TAX STIMULUS

\begin{tabular}{|c|c|c|}
\hline Alternative answers & Frequency & Percentage \\
\hline Yes & 5 & 10 \\
\hline No & 15 & 90 \\
\hline Answer & $\mathbf{2 0}$ & $\mathbf{1 0 0}$ \\
\hline
\end{tabular}

As shown in Table II, as many as $90 \%$ of MSME business actors did not understand the types of tax stimulus provided by the government. From these results, in general, it can be stated that many MSME business actors did not understand what the stimulus was and how to utilize it.

TABLE III. DISTINGUSHING TAX STIMULUS FROM OTHER TYPES STIMULUS

\begin{tabular}{|c|c|c|}
\hline Alternative answers & Frequency & Percentage \\
\hline Yes & 20 & 100 \\
\hline No & 0 & 0 \\
\hline Answer & $\mathbf{2 0}$ & $\mathbf{1 0 0}$ \\
\hline
\end{tabular}

With regard to distinguishing tax stimulus from other types of stimulus, as shown in Table III, all MSME business actors thought that the tax stimulus was the same as government stimulus in other field such as Pre-employment cards, PKH (Program Harapan Keluarga) or commonly known as one of family programs offer by Indonesian government, KIP (Kartu Indonesia Pintar) or The Smart Indonesian Card, and others. This indicates that business actors have not been able to distinguish the types of assistance provided by the government.

TABLE IV. THE NEED FOR TAX STIMULUS SOCIALIZATION, ESPECIALLY MSMES

\begin{tabular}{|c|c|c|}
\hline Alternative answers & Frequency & Percentage \\
\hline Yes & 20 & 100 \\
\hline No & 0 & 0 \\
\hline Answer & $\mathbf{2 0}$ & $\mathbf{1 0 0}$ \\
\hline
\end{tabular}

Based on the distribution of questionnaires distributed, as shown in Table IV all business actors viewed the importance of socializing the fiscal stimulus, especially in the MSME sector.

Regarding the tax stimulus provided by the government during the Covid-19 pandemic, MSME actors did not comprehend thoroughly the type of stimulus. They presumed that the stimulus provided by the government, be it in the fields of education, manpower, and social affairs are equal to the stimulus in the field of taxation of 90 percent. This certainly affects the perception of MSME business actors on Government performance in the fiscal sector, and all informants stated the need to socialize the type of stimulus and how the pattern of its application is. As many as 50 percent 
admitted that the presence of the stimulus from the government made their business more enthusiastic than before given the stimulus. However, this stimulus was not aimed at fiscal stimulus but rather government assistance in other fields such as pre-employment, PKH, KIP, and others. As a result of this lack of comprehending, MSME business actors do not comprehend the types of stimuli in the taxation sector.

From the results, it can be discovered that all business actors are aware of the function of government assistance (stimulus) for the community, this indicates that MSME business actors really hope for further assistance from the government so that their businesses can survive the Covid-19 pandemic.

\section{CONCLUSION}

Based on the research conducted, it can be concluded that MSME business actors expected government assistance in the field of MSMEs so that their businesses can survive during the Covid-19 pandemic. Business actors were directly aware of the existence of government assistance but did not know which ministry it is from therefore there is a need for socialization from the government regarding the assistance (stimulus).

\section{REFERENCES}

[1] H. Wijoyo, "The Role of Tax Law in Economic Development (Peranan Pajak Dalam Pembangunan Ekonomi)," In Jurnal Ilmiah Ekonomi dan Bisnis, vol. 2, no. 1, 2005.

[2] D. Sunarsi, H. Wijoyo, D. Prasada, and D Andi, "The Effect of The Work Environment on Employee Performance at PT. Mentari Persada in Jakarta," In Seminar Nasional Manajemen, vol 5, no. 2, 2020.

[3] H. Wijoyo, "The Role of Tax Law in Economic Development (Peranan Hukum Pajak Dalam Pembangunan Ekonomi)," In Jurnal Hukum Respublica, vol 4, no. 2, 2005.

[4] A. Ahmadun, "Empowerment of MSMEs for Family Businesses in Increasing Income in Jangkar Village, Mekarwangi Cariu Village, Bogor," Jurnal Pelayanan Dan Pengabdian Masyarakat, vol 3, no. 1, pp. $35-42,2019$.
[5] S. Palimbong, A. Nurwarista, and S. M. Istimur, S. M, "Potential Utilization of Local Flour Sources as Wheat Substitution," Inovatif Pengabdian Masyarakat, vol 2, no. 2, pp. 1-6, 2019.

[6] L. L. Maleong, Tehnik Penelitian Kualitatif (Edisi Revisi). Bandung: PT. Remaja Rosdakarya, 2012.

[7] H. Wijoyo and M. Yahya, "Developing School Information Program: Integrated Management System based on Character Value at SMP Negeri 9 Tapung," International Journal of Asian Education, vol. 1, no. 3, pp. 179-186, 2020.

[8] W. Widiyanti and H. Wijoyo, "Paving Block Marketing Analysis At Cv Mekar Jaya Pekanbaru," In International Jornal of Business and Information Technology, vol 1, no. 1, 2020.

[9] H. Haudi, H. Wijoyo, and Y. Cahyono, "Effect of Product Innovation and Marketing Strategy on Consumer Purchase Decisions in Indonesia's Lightweight Roof Steel Industry," In Journal of Critical Reviews, vol 7, no. 13, 2020.

[10] H. Wijoyo and W. Widiyanti, "Post-Pandemic Covid-19 MSME Digitalization in Riau," Prosiding Sinagara: Inovasi Dalam Mewujudkan SDG's Pada Era Post Pandemik, vol 1, no.2, pp. 12-16, 2020. 